\title{
1201 車体構造を構成するアルミ中空押出形材の音響透過損失特性
}

Acoustic Transmission Loss Property of Aluminum Hollow Structure for Railway Carbody

\author{
○谷井 茂紀（日本車両）丹羽 英樹（日本車両）正 佐々 孝光（日本車両）
}

Shigeki YATSUI, Nippon Sharyo, 2-20, Honohara, Toyokawa, Aichi

Hideki NIWA, Nippon Sharyo, 2-20, Honohara, Toyokawa, Aichi

Takamitsu SASSA, Nippon Sharyo, 2-20, Honohara, Toyokawa, Aichi

\begin{abstract}
Aluminum hollow structure is adopted to railway carbodies to improve specific stiffness, but the acoustic transmission loss property of the hollow structure has not been examined in detail. We study the transmission loss with numerical analysis technique, and find out that the transmission loss is worse than the single plate with equivalent mass at the frequency, at which the 1st vibration mode of each plate element separated by rib is excited. This phenomenon occurs to arbitrary cross section structure with rib, therefore it is not easy to simultaneously improve the specific stiffness and the acoustic transmission loss property. We find that the numerical analysis result coincides with experiment data very well.
\end{abstract}

Key Words: Acoustic Transmission Loss, Hollow Structure, Boundary Element Method, Vibro-Acoustic Coupled Analysis

\section{1.はじめに}

鉄道車両の構体には効率的な軽量化・比剛性向上をはか るためにアルミ中空押出形材（以下、ホロー材）が使用さ れいる。しかしながら、ホロー材の音響透過損失特性につ いては一般的に良いとされてはいるが詳しく調べられてい ない。そこで固有振動モード解析(FEM) と振動音響連成解 析(BEM)を用いてホロー材の透過損失を数值計算により求 め、特性を把握した。また、実測值による数值解析の検証 も行った。

\section{2.振动音䇾連成解析}

a.解析モデル

鉄道車両に使用されている代表的なホロー材(Fig.1)につ いて透過損失を計算する。透過損失解析は以下の 2 段階の 解析から構成される(1)。

1.固有振動モード解析(FEM)

2.振動音響連成解析 (BEM, Fig.2)

モデルサイズは $0.99 \mathrm{~m} \times 2 \mathrm{~m}$ 、拘束条件は全周単純支持と 完全 Free の 2 種類を考え、音源はいずれのケースも垂直入 射と拡散音場の 2 種類とした。拘束条件を 2 種類考えたの は、実測試験が試験片全周を粘土で固定するという全周単 純支持に比べて遥かに弱い拘束条件で行われたためで、実 測条件はこの 2 種類の拘束条件の中間であると考える。な お、ホロー材中の空気層の透過損失への影響は無視できる ことを別計算にて確認したため、本計算では空気層をモデ ル化していない。

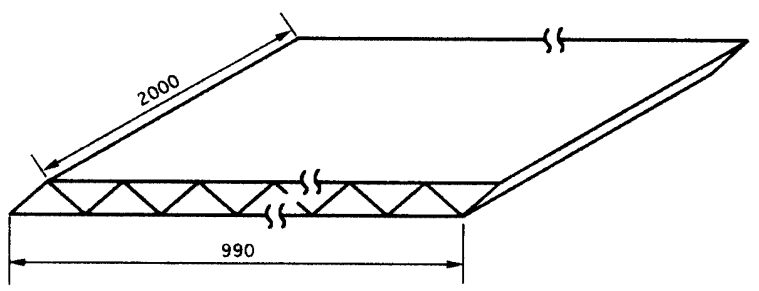

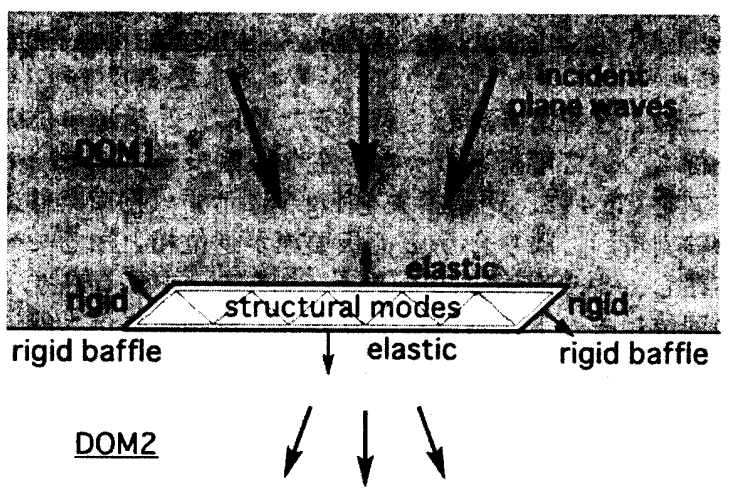

Fig.2: Vibro-Acoustic Coupled Analysis Model (BEM)

\section{b.解析結果}

透過損失解析結果を Fig.3-1,3-2 に示す。

低周波域の透過損失特性は拘束条件の影響を強く受ける。 全周単純支持の場合は全体構造の一次モード周波数の $300 \mathrm{~Hz}$ 付近を極小に、それ以下の周波数では剛性則による 透過損失向上が見られるが、完全 Free の場合は振動モード による大きな落ち込みも剛性則も見られない。一方実測值 は $100 \mathrm{~Hz}$ 付近以下で剛性則が見られ、2 拘束条件の中間的 振舞いとなっていることが分かる。

次に高周波域では、拘束条件によらず $1 \mathrm{kHz}$ 付近に透過損 失の大きな落ち込みが見られる。実測值においても解析よ りやや高い周波数に透過損失の落ち込みが確認できる。こ れらの透過損失の落ち込みは、ホロー材の部分構造モード 励起によるものである。つまり、リブで仕切られた多数の 面板要素の一次モードが $1 \mathrm{kHz}$ 付近に集中して存在してお り、それらのモード励起によって透過損失が悪化している と考えられる。

Fig.1: Test Piece of Hollow Structure

〔No.03-51〕日本機械学会第 12 回交通・物流部門大会講演論文集〔2003-12.9～11. 川崎〕 


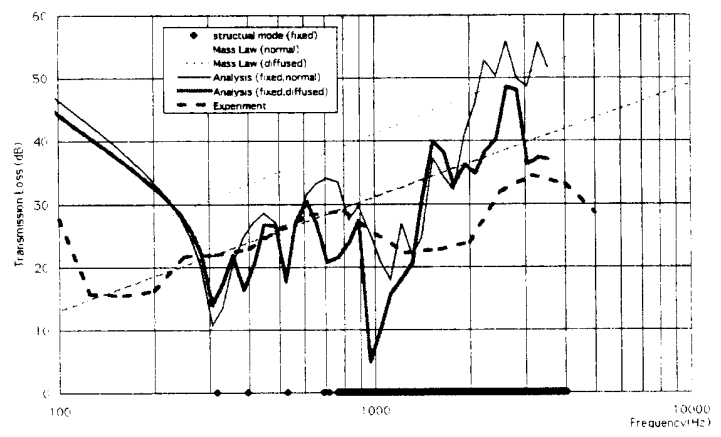

Fig. 3-1:Transmission Loss of Hollow Structure(Fixed Boundary)

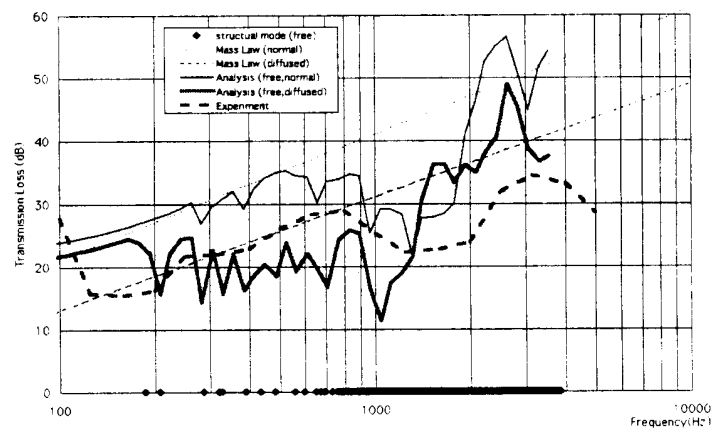

Fig.3-2:Transmission Loss of Hollow Structure (Free Boundary)

このことをより詳しく調べるために、2 構造単位のホロ 一材について解析を行った。主な振動モードのモードシェ イプを Fig.4に、透過損失を Fig.5 に示す（拘束条件は全周 単純支持）。隣り合う 2 面板要素が逆位相となるモードが 存在し、やや高周波に同位相となるモードが存在する。そ の同位相モードに対応した周波数で透過損失が大幅に悪化 していることが分かる。これは同位相モードが(特に垂直入 射により)共鳴励起されやすく、かつ放射効率の高いモード シェイプのためである。
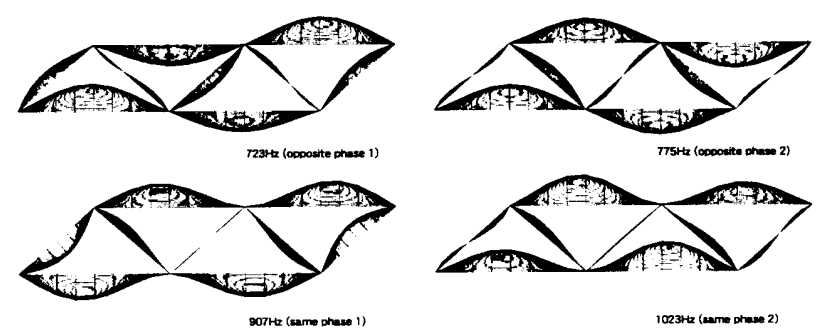

Fig.4: Modeshapes of 2-unit Hollow Structure

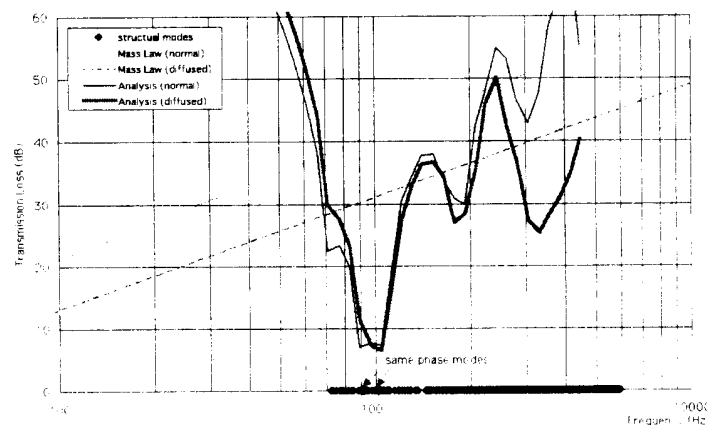

Fig.5: Transmission Loss of 2-unit Hollow Structure

また、逆位相モードと同位相モードがほぼ縮退して存在 するということは、リブで仕切られた各面板要素がお互い
にほぼ独立な振舞いをすることを示している。従ってホロ 一材の断面形状によらず、リブによる仕切りがある限り部 分構造のモード励起による透過損失悪化は必ず起きるもの と考えられる。

Fig.3において解析結果の方が実測よりやや低周波に部 分構造モード励起による透過損失悪化が見られたのは、シ エル要素によるモデル化(Fig.6)により各面板要素のスパン が実際より長く表現されているためである。正しいスパン を表現するため hex 要素を用いて解析を行った結果、モー ド周波数は約 1.4 倍になることを確認した。そこでシェル 要素による解析結果に対して部分構造モードが現れる周波 数域について周波数を 1.4 倍にシフトさせて表示した透過 損失のグラフ(1/3 octave band)を Fig.7 に示す。部分構造モー ド励起による透過損失悪化の周波数は解析と実測の間で非 常に良く一致していることがわかる。
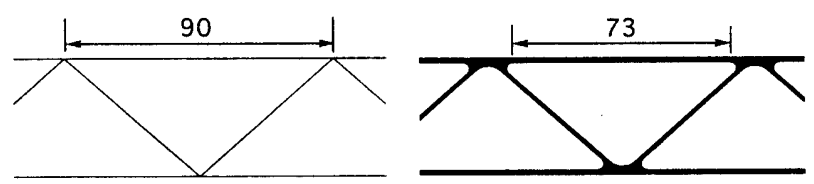

Fig.6: Span Difference between Shell and Hex Models

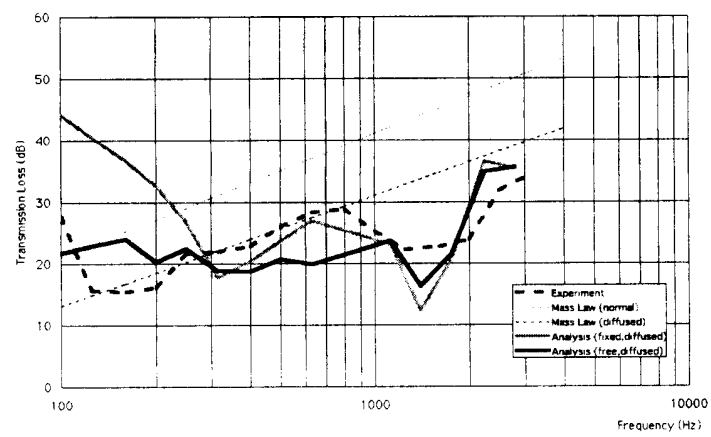

Fig.7: Verification of Numerical Analysis (Transmission Loss of Hollow Structure)

3.まとめ

数值解析の結果、ホロー材の透過損失は部分構造の各面 板要素の一次モード周波数で等価質量単板より悪化するこ とが分かった。これは押出形材の断面形状によらずリブが 存在する限り必ず起きる現象であり、軽量化・比剛性向上 と音響透過損失特性向上の雨立は難しい問題であるといえ る。但し鉄道車両に用いられている代表的なホロー材の場 合、部分構造のモード周波数は $1 \mathrm{kHz}$ 以上の高周波域となる ため制振材や吸音材により効率的に音響特性を改善するこ とが可能である。また、実測值と解析結果との間で透過損 失特性がよく一致し、数值解析の妥当性を検証することが できた。

\section{参考文献}

(1) J. Ben Mariem and M. A. Hamdi, "A New Boundary Finite Element Method For Fluid-Structure Interaction Problems", International Journal for Numerical Methods in Engineering, Vol. $24,1251-1267(1987)$ 